\title{
Mononuclear versus Binuclear Metal-Binding Sites: \\ Metal Binding Affinity and Selectivity from PDB Survey and DFT/CDM Calculations
}

\author{
Tsung-Ying Yang, ${ }^{\dagger}$ Todor Dudev, ${ }^{*, \ddagger}$ and Carmay Lim ${ }^{*,+, \neq}$
}

Contribution from the Institute of Biomedical Sciences, Academia Sinica, Taipei 115 and the Department of Chemistry, National Tsing Hua University, Hsinchu 300, Taiwan 
Ref. 32. Frisch, M. J.; Trucks, G. W.; Schlegel, H. B.; Scuseria, G. E.; Robb, M. A.;

Cheeseman, J. R.; Montgomery, J. A., Jr.; Vreven, T.; Kudin, K. N.; Burant, J. C.;

Millam, J. M.; Iyengar, S. S.; Tomasi, J.; Barone, V.; Mennucci, B.; Cossi, M.; Scalmani, G.; Rega, N.; Peterson, G. A.; Nakatsuji, H.; Hada, M.; Ehara, M.; Toyota, K.; Fukuda, R.; Hasegawa, J.; Ishida, M.; Nakajima, T.; Honda, Y.; Kitao, O.; Nakai, H.; Klene, M.; Li, X.; Knox, J. E.; Hratchian, H. P.; Cross, J. B.; Adamo, C.; Jaramillo, J.; Gomperts, R.; Stratmann, R. E.; Yazyev, O.; Austin, A. J.; Cammi, R.; Pomelli, C.; Ochterski, J. W.; Ayala, P. Y.; Morokuma, K.; Voth, G. A.; Salvador, P.; Dannenberg, J. J.; Zakrzewski, V. G.; Dapprich, S.; Daniels, A. D.; Strain, M. C.; Farkas, O.; Malick, D. K.; Rabuck, A. D.; Raghavachari, K.; Foresman, J. B.; Ortiz, J. V.; Cui, Q.; Baboul, A. G.; Clifford, S.; Cioslovski, J.; Stefanov, B. B.; Liu, G.; Liasehenko, A.; Piskorz, P.; Komaromi, I.; Martin, R. L.; Fox, D. J.; Keith, T.; Al-Laham, M. A.; Peng, C. Y.; Nanayakkara, A.; Challacombe, M.; Gill, P. M. W.; Johnson, B.; Chen, W.; Wong, M. W.; Gonzalez, C.; Pople, J. A. Gaussian 03, rev. B.03; Gaussian, Inc.: Pittsburgh, PA, 2003. 

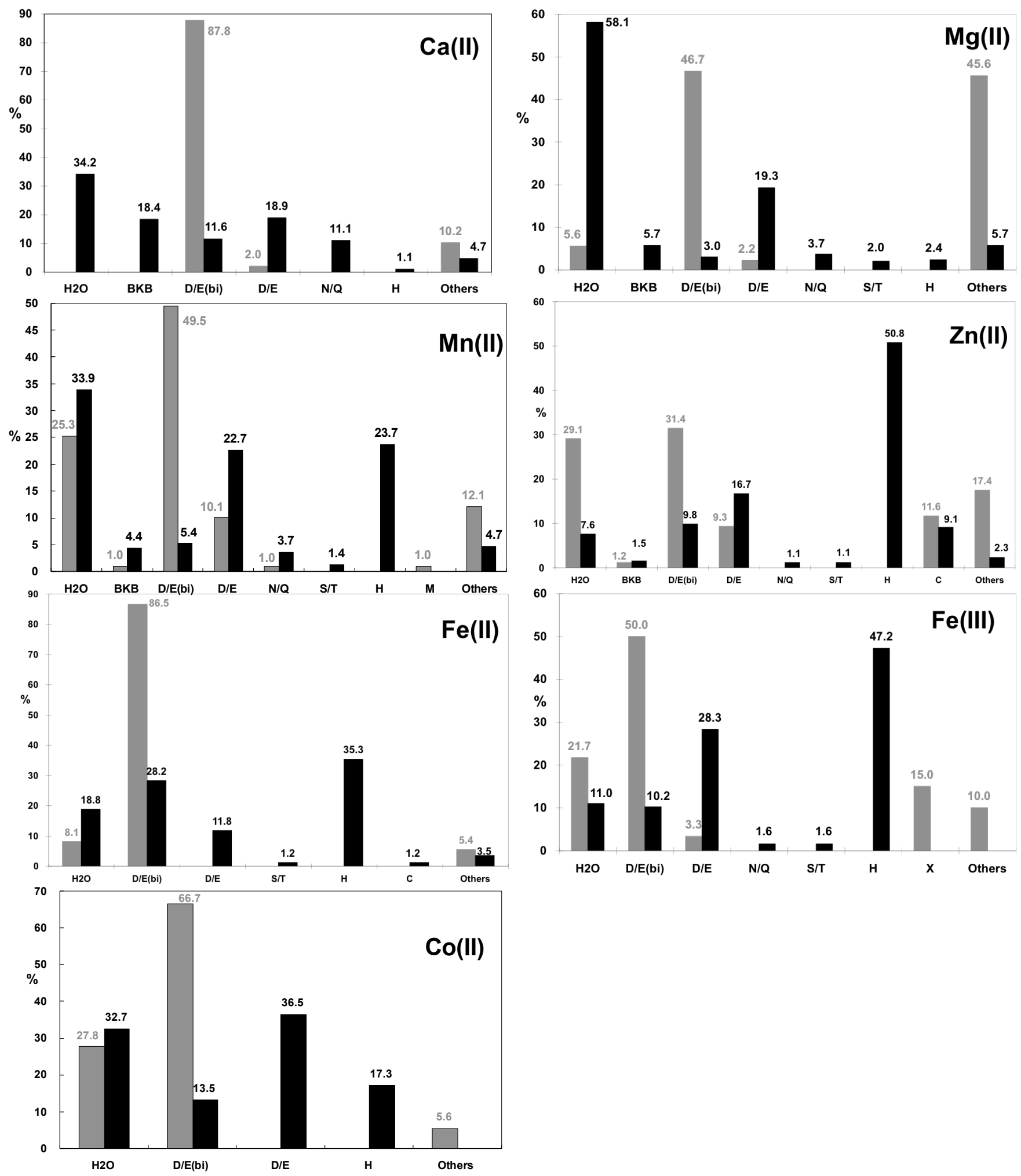

Figure S1. Percentage frequency distribution of $1^{\text {st }}-$ shell ligands observed in the PDB structures of proteins containing homo-binuclear binding sites. The grey and black bars represent the $\%$ frequency distributions of the bridging and non-bridging ligands, respectively. "H2O" denotes water, "BKB" denotes the backbone group, "D/E(bi)" 
means that both Asp/Glu carboxylate oxygen atoms are bound to the metal ion, "Others" denotes non-protein/water ligands, " $\mathrm{X}$ " means either a hydroxide $\mathrm{O}^{-}$or $\mathrm{O}^{2-}$, while the other letters denote the amino acid side chain that is bound to the metal ion. 